\title{
Effects of underlay on hill-slope surface runoff process under different rainfall intensities
}

\author{
Bingchen $\mathrm{Wu}^{1}$ and Shi $\mathrm{Qi}^{1}$ \\ ${ }^{1}$ Beijing Forestry University
}

November 13, 2020

\begin{abstract}
Clarifying the impact of underlay (i.e., the combination of understory vegetation and surface micro-topography) on the surface runoff process under different rainfall intensities would provide a significant theoretical basis for controlling soil and water loss on steep slopes in mountainous areas of southwestern China. In the current study, the runoff process under different rainfall intensities was observed based on 10 natural runoff plots, and the correlation between the spatial pattern of cypress (Cupressus funebris), micro-topography and runoff characteristic parameters was tested using the Pearson correlation coefficient method. The effects of the spatial pattern of cypress and micro-topography on surface runoff also were analyzed using the Response Surface Method (RSM). The results indicated that the blocking effects of different underlay conditions on surface runoff decreased with the increase of rainfall intensity. The impact of the spatial pattern of cypress and micro-topography on the runoff process was mainly reflected in the impact on peak flow. Under the condition of moderate rainfall (30-50 mm/24 h) or rainstorm (50-70 $\mathrm{mm} / 24 \mathrm{~h}$ ), topographic relief, surface roughness, runoff path density, contagion index of cypress, and stand density of cypress were the key factors that affected the peak flow, whereas under the condition of severe rainstorms $(>70 \mathrm{~mm} / 24 \mathrm{~h})$ none of the foregoing factors had a significant correlation with peak flow. Under the conditions of moderate rainfall or rainstorm, when the composite indexes of the spatial pattern of cypress and micro-topography were small, the peak flow would not be significantly affected. When the micro-topography reached the conditions required to significantly increase the peak flow, increasing the composite index of the spatial pattern of cypress within a certain range promotes the peak flow, and when the composite index of the spatial pattern of cypress exceeded a certain value, as the composite index of micro-topography increased, the dominant factor affecting the peak flow gradually changed from the spatial pattern of cypress to that of micro-topography.
\end{abstract}

\section{Introduction}

Hillslope-scale surface runoff is a hydrological process which occurs on the complex underlay and is affected by multiple factors (Xu et al., 2019; González-Arqueras et al., 2018; Ochoa et al., 2016). Vegetation and topography are the basic elements of the underlay and have an important influence on the surface runoff process (El Kateb et al., 2013).

At present, most studies have focused on the relation between vegetation type or quantity and runoff process (Burylo et al., 2012; Duan et al., 2016). Some studies have investigated the influence of both vegetation coverage and topographic factors on the runoff process through simulation experiments (Ren et al., 2018; Hou et al., 2020), only a few studies have pointed out that the impact of vegetation on the runoff process and hydraulic characteristics was not only related to the type and quantity of vegetation, but also to the spatial distribution of vegetation (Zhao et al., 2019; Puigdefábregas, 2010). However, limited by the complexity of the spatial pattern and hydrological processes, which is a frontier issue in geosciences and ecology, little empirical work testing the hypothetical covariation between vegetation spatial structure and hillslope-scale surface runoff has been done (Fu et al., 2005; Bautista et al., 2007; Qin et al., 2017).

Previous studies on the relations between vegetation pattern and hillslope runoff, often give a qualitative 
description of the vegetation pattern according to patch shape, distribution density, and uniformity, and then compare and analyze the difference in runoff corresponding to different spatial patterns. For example, Zhang et al (2014) indicated that a checkerboard pattern, banded pattern, and a pattern with small patches distributed like the letter $\mathrm{X}$ performed more effectively than a single long strip parallel to the slope direction in increasing hydraulic roughness on the basis of artificial rainfall simulation experiments. Yang et al (2015) studied the influence of four vegetation patterns on the hydrodynamics of surface flow, and found that a stagger pattern had the best effect on suppressing flow velocity.

The foregoing research showed that the impact of vegetation pattern on the runoff process was mainly reflected in the dispersion of runoff and the consumption of runoff energy. In fact, vegetation pattern is closely related to micro-topography (Ito et al., 2017), and studies have shown that the heterogeneity of microhabitats caused by changes in micro-topography are considered to be the main factor in the development of plant species diversity and the formation of vegetation patterns (Efe, 2014; Du et al., 2017). The lateral variation of the slope, and aspect patterns as well as the distribution of bare rock affect the redistribution of rain, heat, and soil nutrients, indirectly defining a mosaicked pattern for vegetation assemblages (Székely et al., 2015). On the contrary, the distribution of trees, surface vegetation and litter caused differences in soil properties and surface roughness, and changed the deposition and migration of soil particles, which indirectly reshaping the micro-topography (Milisa et al., 2010).

The overlapping pattern formed by vegetation and micro-topography is the result of the long-term interaction and co-evolution of these two factors (Saco and Mariano, 2013; Kim and Kupfer, 2016), which together determine the runoff path structure of the slope unit, and enhance or weaken the water blocking capacity of the landscape system, thereby changing the intensity and distribution of runoff (Slattery and Burt, 2015). Therefore, it was difficult to fully reveal the influence of complex underlay on the runoff process if the difference in the runoff generation was only attributed to the vegetation pattern without considering the overlapping pattern formed by vegetation and micro-topography. In addition to the difference in the underlay, rainfall factors affect the runoff process in the process of soil saturation and water convergence. When the rainfall exceeds a certain threshold, the fast channel of water flow was connected, resulting in the dynamic change of the surface runoff coefficient (Meerveld and Mcdonnell, 2006; Liu et al., 2019), thereby deepening the complexity of the impact of underlay conditions on the runoff process. Therefore, to study the effect of vegetation pattern on hillslope runoff, it was necessary to clarify the key role of vegetation pattern and micro-topography factors in the runoff process under different rainfall conditions.

The mountainous regions in southwest China have highly complex geological structures, diverse topography, and humid climates. Forest ecosystems developed in such mountainous environments have steep slopes and shallow soil characteristics, and the ecosystem was relatively vulnerable (Febles-Gonzalez et al., 2011; Bai et al., 2012). Cypress (Cupressus funebris), as the main afforestation tree species in the southwestern mountains, was widely used on steep slopes where the soil was barren and vegetation restoration was hard to achieve. This study was based on the field observation experiment of natural runoff plots. The runoff process was observed under different rainfall intensities, quantitative relations between factors of the spatial pattern of cypress and micro-topography and runoff characteristics parameters were analyzed to reveal the effect of the spatial pattern of cypress and micro-topography on the runoff process, which would provide theoretical support for the control of soil erosion on steep slopes in mountainous areas in southwestern China.

\section{Materials and methods}

\subsection{Site description}

The study area was located in the subtropical humid monsoon climate zone, with an average annual precipitation of $1200 \mathrm{~mm}$. Most of the rainfall occurred between May and August, accounting for $70 \%$ of the annual precipitation. The annual average temperature of the region was 18 , ranging from -2 to 42 . The study was done on a steep slope (slope angle>30deg) in Huaying County (30deg25'21"N, 106deg50'2"E), Sichuan Province. The slope was a bedding slope and the soil was limestone yellow soil. The slope was composed of cypress and sparse weeds, with an area of $0.5 \mathrm{~km}^{2}$ and an elevation of $565-600 \mathrm{~m}$. The cypress forest on 
the slope originated from the Grain-for-Green Project at the beginning of the 21st century. Aerial-seeding afforestation was done on the degraded slope. After two decades of succession of vegetation communities, the slope has developed into an open-canopied cypress forest, with significant differences in stand density and distribution patterns.

\subsection{Experiment design}

\subsubsection{Runoff plot setting}

Ten natural runoff plots $(5 \mathrm{mx} 10 \mathrm{~m})$ were built at the same slope position, and the relative height difference of each runoff plot was basically the same to ensure consistency of the gravitational potential energy for each runoff plot. The basic characteristics of each runoff plot are listed in Table 1.

\subsubsection{Data collection and processing}

For each runoff plot, measured data including the spatial distribution of cypress, micro-topography, rainfall, and surface runoff were collected. A Real-Time Kinematic (RTK) Global Positioning System (GPS) was used to mark the spatial position of cypress. For the description of the spatial pattern of cypress, indicators such as the Ripley's (1977) K index, the contagion index (Pommerening, 2002; Aguirre et al., 2003), and the stand density were used for characterization. In this study, Ripley's K index described the number of individual plants in a circle with a point as the center and $\mathrm{r}$ was the radius, which is typically used to compare a given point distribution with a random distribution:

\section{Hosted file}

image1.wmf available at https://authorea.com/users/357914/articles/492759-effects-ofunderlay-on-hill-slope-surface-runoff-process-under-different-rainfall-intensities

with

$I_{r}\left(u_{\mathrm{ij}}\right)=\{$

$\begin{aligned} 1, & u_{\mathrm{ij}}<r \\ 0, & u_{\mathrm{ij}}>r\end{aligned}$ and $0[?] I_{r}\left(u_{\mathrm{ij}}\right)[?] 1(1)$

where $\mathrm{N}$ is the total number of trees, and $u_{\mathrm{ij}}$ is the distance between $\mathrm{i}$ and $\mathrm{j}$.

The K-function can be normalized as L-function proposed by Besag (1977):

\section{Hosted file}

image2.wmf available at https://authorea.com/users/357914/articles/492759-effects-ofunderlay-on-hill-slope-surface-runoff-process-under-different-rainfall-intensities

A positive value of $\mathrm{L}(\mathrm{r})$ indicates clustering over that spatial scale whereas a negative value indicates dispersion.

The contagion index, $W_{i}$ describes the degree of regularity of the spatial distribution of the four trees nearest to a reference tree i. $W_{i}$ was based on the classification of the angles between these four neighbors. A reference quantity is the standard angle, $\alpha_{0}$, which was expected in a regular point distribution. The binary random variable, $z_{\mathrm{ij}}$, was determined by comparing each $\alpha_{j}$ with the standard angle $\alpha_{0}=90$, and the contagion index $W_{i}$ is then defined as the proportion of angles $\alpha_{j}$ between the four neighboring trees which were smaller than the standard angle $\alpha_{0}$ :

\section{Hosted file}

image3.wmf available at https://authorea.com/users/357914/articles/492759-effects-ofunderlay-on-hill-slope-surface-runoff-process-under-different-rainfall-intensities 
with

$z_{\mathrm{ij}}=\{$

$1, \quad \alpha_{j}<\alpha_{0} \quad$ and $0[?] W_{i}[?] 1(3)$

$W_{i}$ equal to zero indicates that the trees in the vicinity of the reference tree are positioned in a regular manner, whereas $W_{i}$ equal to one points to an irregular or clumped distribution.

The value range and meaning of the contagion index, $W_{i}$, are further clarified in Fig. 1 . In this study, the average of the contagion index, $W$, calculated for each standard tree was used as the comprehensive contagion index of each runoff plot:

\section{Hosted file}

image4.wmf available at https://authorea.com/users/357914/articles/492759-effects-ofunderlay-on-hill-slope-surface-runoff-process-under-different-rainfall-intensities

RTK-GPS also was used to measure the micro-topography for each runoff plot. During the measurement process, spatial point data were measured at $0.2 \mathrm{~m}$ intervals, and when encountering areas with large terrain variability, intensive measurements were done at $0.1 \mathrm{~m}$ intervals. Topographic relief (Normark and Spiess, 1976), surface roughness (Romkens et al., 2002), surface cutting depth (He et al., 2016), and runoff path density (Zhao and Govers, 2016) were used to describe the characteristics of micro-topography for each runoff plot. 


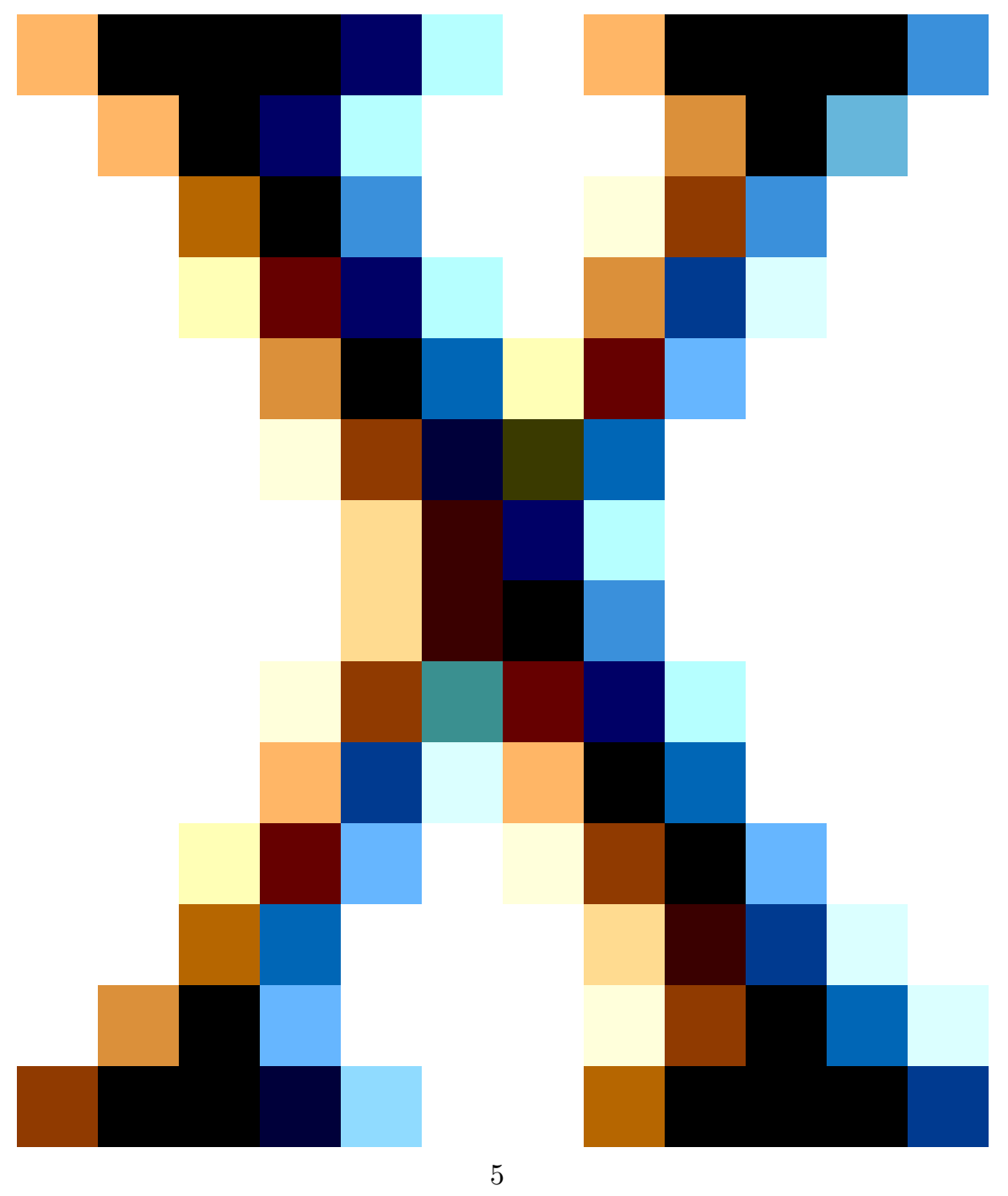




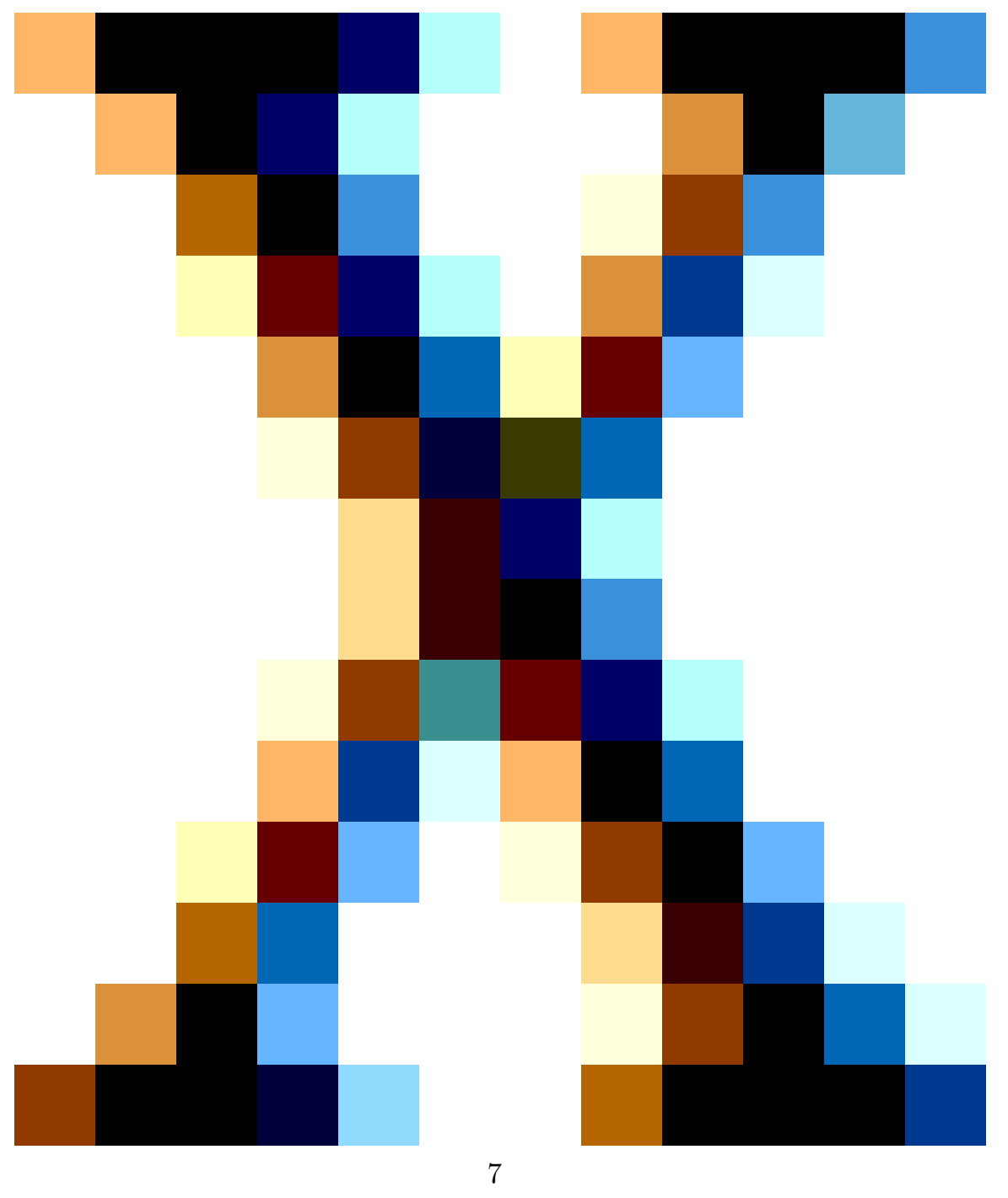


Topographic relief was calculated based on change-point theory. First, the average value,, was calculated according to the elevation value of $0.2 \mathrm{~m}$ grid points $\left\{\mathrm{X}_{1}, \mathrm{X}_{2}, \mathrm{X}_{3} \ldots \mathrm{X}_{\mathrm{n}}\right\}$ in the runoff plot, and then the average topographic relief of the runoff plot could be calculated:

\section{Hosted file}

image6.wmf available at https://authorea.com/users/357914/articles/492759-effects-ofunderlay-on-hill-slope-surface-runoff-process-under-different-rainfall-intensities

where $\mathrm{S}$ is the average topographic relief and $\mathrm{n}$ is the number of grid points.

Surface roughness was calculated by the ratio of the surface area and the projected area of the runoff plot which were extracted using the three-dimensional (3D) Analyst tool in ArcGIS:

\section{Hosted file}

image7.wmf available at https://authorea.com/users/357914/articles/492759-effects-ofunderlay-on-hill-slope-surface-runoff-process-under-different-rainfall-intensities

(6)

where $S_{1}$ is the surface area of the runoff plot, and $S_{2}$ is the projected area of the runoff plot.

The runoff path refers to the shallow trench formed by surface runoff, while the runoff path density was the total length of the runoff path per unit area. In this study, the RTK-GPS was used to measure the runoff path length, and the hydrological analysis tool in ArcGIS was used for secondary inspection:

\section{Hosted file}

image8.wmf available at https://authorea.com/users/357914/articles/492759-effects-ofunderlay-on-hill-slope-surface-runoff-process-under-different-rainfall-intensities

where $L_{i}$ is the length of the $\mathrm{i}$-th groove in the runoff plot, and $\mathrm{A}$ is the area of the runoff plot.

The surface cutting depth refers to the difference between the average elevation and the minimum elevation of a certain point on the ground. In this study, the surface cutting depth was calculated using the elevation data of each point in the neighborhood of the runoff path:

\section{Hosted file}

image9.wmf available at https://authorea.com/users/357914/articles/492759-effects-ofunderlay-on-hill-slope-surface-runoff-process-under-different-rainfall-intensities

where $Y_{i}$ is the average elevation within the neighborhood of the i-th point on the bottom line of the runoff path, $Y_{\text {imin }}$ is the minimum elevation of the $\mathrm{i}$-th point on the bottom line of the runoff path, and $\mathrm{m}$ is the number of points on the bottom line of all runoff paths in the runoff plot.

The runoff process of each runoff plot is reflected by the water level gauge data of the receiving reservoir. The meassurement time interval of the water level gauge was $10 \mathrm{~min}$. The runoff characteristic parameters included runoff duration, runoff volume, and peak flow.

\subsection{Statistical methods}

\subsubsection{Correlation analysis}


To determine the key factors that had a significant impact on the runoff process, the Pearson correlation coefficient method was used to test the correlation between the factors of the spatial patterns of cypress and micro-topography, and the characteristic parameters of the runoff process.

\subsubsection{Response surface method}

To reveal the comprehensive influence of the spatial pattern of cypress and micro-topography on the runoff process, the Response Surface Method (RSM) was used to construct 3D surface equations between the factors of the spatial patterns of cypress and micro-topography, and characteristic parameters of the runoff process under different rainfall events.

\section{Results}

3.1. Runoff process of each runoff plot with different rainfall intensity

From June 2019 to October 2019, a total of 20 rainfall events were monitored, with rainfall intensity ranging from $9.8 \mathrm{~mm} / 24 \mathrm{~h}-72.2 \mathrm{~mm} / 24 \mathrm{~h}$. Among the rainfall events that caused surface runoff, the minimum rainfall intensity was $33.8 \mathrm{~mm} / 24 \mathrm{~h}$, and the maximum rainfall intensity was $72.2 \mathrm{~mm} / 24 \mathrm{~h}$. According to the classification standard, the rainfall intensity that caused surface runoff in the study area could be divided into three rainfall conditions: moderate rainfall $(30-50 \mathrm{~mm} / 24 \mathrm{~h})$, rainstorm $(50-70 \mathrm{~mm} / 24 \mathrm{~h})$, and severe rainstorm $(>$ $70 \mathrm{~mm} / 24 \mathrm{~h}$ ). Three typical rainfall events on June 29 (rainfall intensity of $51.8 \mathrm{~mm} / 24 \mathrm{~h}$ ), July 22 (rainfall intensity of $33.8 \mathrm{~mm} / 24 \mathrm{~h}$ ), and August 8 (rainfall intensity of $72.2 \mathrm{~mm} / 24 \mathrm{~h}$ ) were selected as examples, and the runoff process were shown in Figs. 2, 3, and 4.

Comparing the runoff process under these three typical rainfall events (Figs. 2, 3, and 4), it can be seen that when the rainfall event was the same, the time of the peak flow in each runoff plot was basically the same. As the rainfall intensity changed from moderate rainfall to severe rainstorm, the time of the peak flow in each runoff plot reduced from 140 to $70 \mathrm{~min}$. Under the same rainfall conditions, there were differences in the peak flow for each runoff plot, and as the rainfall intensity changed from moderate rainfall to severe rainstorm, the difference of the peak flow among each runoff plots gradually decreased.

To reflect the difference in the hindering effect of the underlay on surface runoff under different rainfall conditions, the differences in the peak flow coefficients (Deng, 2014) for each runoff plots are compared under the condition of moderate rainfall, rainstorm, and severe rainstorm as listed in Table 2.

Table 2 shows that for the different runoff plots, as the rainfall condition changed from moderate rainfall to severe rainstorm, the peak flow coefficients all increased, indicating that as the rainfall intensity increased, the hindering effect of the different underlay conditions on the surface runoff all decreased.

3.2. Influence of the spatial pattern of cypress and micro-topography on peak flow under different rainfall intensities

As the peak flow from different underlay conditions was different under the same rainfall condition, the difference in peak flow between different underlay conditions gradually decreased when the rainfall intensity changed from moderate rainfall to severe rainstorm. So the relation between the characteristics of the underlay and the peak flow under different rainfall intensities was the core of the current research.

The standard deviations of the surface vegetation coverage, soil thickness and relative height difference of the ten runoff plots were $2.25 \%, 1.21 \mathrm{~cm}$, and $0.13 \mathrm{~m}$, respectively, which were not of the same order of magnitude as the sample data. Therefore, the effects of the variations of surface vegetation coverage, soil thickness, and relative height difference in this study could be eliminated. From the analysis of the growth status of cypress in each runoff plot, there was no significant difference in the average crown width, average height, and average $\mathrm{DBH}$ of the cypress for each runoff plot, which showed that the growth status of cypress in each runoff plot was basically the same, and the growth stage of cypress was in the juvenile stage, so the influence of canopy interception and stem flow of the cypress on the runoff process was negligible. Therefore, the difference of the underlay condition of each runoff plot was mainly reflected in the spatial patterns of cypress and the micro-topographic features. 
The Pearson correlation coefficient method was used to test the correlation among the factors of the spatial patterns of cypress and micro-topography and peak flow under three typical rainfall events. The results are listed in Table 3. For peak flow, under the condition of moderate rainfall or rainstorm, topographic relief, surface roughness, runoff path density, contagion index of cypress, and stand density of cypress were significantly correlated with peak flow $(\mathrm{P}<0.05)$, indicating that these five factors were the key factors affecting the peak flow under moderate rainfall or rainstorm. However, under the condition of severe rainstorm, no significant correlation was found between each factor and the peak flow, indicating that the underlay was no longer the dominant factor affecting the peak flow.

3.3. Influence of the spatial pattern of cypress and micro-topography on peak flow under the condition of moderate rainfall or rainstorm

3.3.1. Correlation between the composite index of the spatial pattern cypress/ micro-topography and peak flow

The composite index was constructed to simplify the complex relation between multiple factors and peak flow. According to the test results of the correlation between the factors of the spatial pattern of cypress and micro-topography, and the peak flow, under moderate rainfall or rainstorm, topographic relief, and runoff path density were positively correlated with peak flow, while surface roughness, contagion index of cypress, and stand density of cypress were negatively correlated with peak flow. Therefore, the topographic relief*runoff path density/surface roughness was used as the composite index of micro-topography, and the contagion index of cypress*the stand density of cypress was used as the composite index of the spatial pattern of cypress.

The Pearson correlation coefficient method was used to test the correlation between the composite index of micro-topography and the composite index of the spatial pattern of cypress and the peak flow (Table 4). The results showed that under moderate rainfall or rainstorm, the composite index of micro-topography was significantly positively correlated with the peak flow, and the composite index of the spatial pattern of cypress was significantly negatively correlated with the peak flow.

3.3.2. Influence of the spatial pattern of cypress and micro-topography on peak flow under the condition of moderate rainfall

The response surface equations of peak flow to the composite indexes of the spatial pattern of cypress and micro-topography under moderate rainfall was constructed using the RSM which is shown as follows:

$\mathrm{Q}_{\mathrm{p}}=0.316 \mathrm{U}^{2}-0.02 \mathrm{~V}^{2}+0.079 \mathrm{U}^{*} \mathrm{~V}-5.51 \mathrm{U}+0.29 \mathrm{~V}+28.5(9)$

where $Q_{p}$ is the peak flow, $U$ is the composite index of micro-topography, and $V$ is the composite index of the spatial pattern of cypress

The response surface and the corresponding contour map are shown in Fig. 5. For area I, the composite indexes of the spatial pattern of cypress and micro-topography were both at low values, and the peak flow in this area did not significantly change with the changes of the composite indexes of the spatial pattern of cypress or micro-topography. For area II, the composite index of the spatial pattern of cypress was at low values, but the composite index of micro-topography was at high values, and the peak flow in this area increased with the increase of the composite index of the spatial pattern of cypress or micro-topography, indicating that when the characteristics of micro-topography reached the conditions for significantly increasing the peak flow, increasing the composite index of the spatial pattern cypress within a certain range would not reduce but increase the peak flow. For area III, the composite index of the spatial pattern of cypress was at high values, but the composite index of micro-topography was at low values, and the peak flow in this area did not change significantly with the changes of the composite index of micro-topography, while it decreased significantly with the increase of the composite index of the spatial pattern of cypress. With the transition from area III to area IV, the peak flow increased significantly with the increase of the composite index of micro-topography, but only slightly decreased with the increase of the composite index of the spatial pattern of cypress, indicating that when the composite index of the spatial pattern of cypress exceeded a 
certain value (area III and area IV), as the composite index of micro-topography increased, the dominant factor affecting the peak flow changed from the spatial pattern of cypress to micro-topography.

3.3.3. Influence of the spatial pattern of cypress and micro-topography on peak flow under the condition of rainstorm

The response surface equations of peak flow to the composite index of the spatial pattern of cypress and micro-topography under rainstorm was constructed using the RSM which was shown as follows:

$\mathrm{Q}_{\mathrm{p}}=0.517 \mathrm{U}^{2}-0.0396 \mathrm{~V}^{2}+0.35 \mathrm{U}^{*} \mathrm{~V}-13.8 \mathrm{U}-1.04 \mathrm{~V}+95(10)$

The response surface and the corresponding contour map are shown in Fig.6. For area I, the composite index of the spatial pattern of cypress was at low values, and the peak flow in this area did not significantly change with the changes of the composite index of micro-topography, indicating that when the underlay had no obvious characteristics of the spatial pattern of cypress, changing the micro-topography within a certain range would not have a significant impact on the peak flow. With the transition from area I to area II, the peak flow increased with the increase of the composite index of the spatial pattern of cypress, indicating that when the characteristics of micro-topography reached the conditions for significantly increasing the peak flow, increasing the composite index of the spatial pattern cypress within a certain range would not reduce but increase the peak flow. For area III, the composite index of the spatial pattern of cypress was at high values, but the composite index of micro-topography was at low values, and the peak flow in this area did not significantly change with the changes of the composite index of micro-topography, while it decreased significantly with the increase of the composite index of the spatial pattern of cypress. With the transition from area III to area IV, the peak flow increased significantly with the increase of the composite index of micro-topography, but only slightly decreased with the increase of the composite index of the spatial pattern of cypress. These results indicate that when the composite index of the spatial pattern of cypress exceeded a certain value (area III and area IV), as the composite index of micro-topography increased, the dominant factor affecting the peak flow changed from the spatial pattern of cypress to micro-topography.

\section{Discussion}

4.1. Interaction between the spatial pattern of cypress and micro-topography

According to the correlation test between the factors of the spatial pattern of cypress and micro-topography (Table 3), the interaction between the spatial pattern of cypress and micro-topography was mainly reflected in the negative correlation between the contagion index of cypress and the topographic relief, and the positive correlation between the stand density of cypress and surface roughness.

For the interaction between the stand density of cypress and surface roughness, the main consideration was the shaping effect of individual trees on micro-topography (Song et al., 2003) and the influence of surface roughness on soil infiltration and soil nutrients (Wang et al., 2018). The increase in the stand density of cypress made more micro-habitats form on the slope and caused the difference in surface roughness in each micro-habitat, which finally resulted in a positive feedback mechanism between the stand density of cypress and surface roughness.

For the interaction between the contagion index of cypress and topographic relief, related studies have shown that the formation of the spatial pattern of vegetation strengthens the source-sink effect on the migration of soil material (Imeson and Prinsen, 2004). The resistance of the vegetation patch increased the flow velocity along the edge of the patch, and the formation of the plume structure inhibited soil erosion above the patch, while it enhanced the soil erosion below the patch (Vandenbruwaene et al., 2011; Harman et al., 2014; Bochet et al., 2015). The continuous spatial migration of soil particles made the otherwise uniform slope become undulating. In this study, the higher contagion index of cypress indicated that the spatial pattern of cypress was in a clumped distribution, which was more unfavorable for runoff to pass than a regular distribution. These clumped distributions had a stabilizing effect on the soil in the micro-habitat, reducing the topographical fluctuations caused by soil migration. 
On the other hand, convexity and elevation were the most important variables effecting the distribution of trees (Lan et al., 2011). The impact of convexity on the distribution of trees mainly came from the redistribution of soil and water which led to the spatial heterogeneity of micro-habitats, while the clumped distribution of trees in the karst mountainous area was closely related to the high heterogeneity of microhabitats and the restriction of seed dispersal (Zhang et al., 2015). The increase in topographic relief reduces the maximum gathering radius of trees (Ren et al., 2016), which indicates that higher topographic relief is not conducive to the formation of a clumped distribution of cypress (low contagion index of cypress).

According to the interaction between the spatial pattern of cypress and the micro-topography, combined with the results of response surface analysis, when the underlay was flat with no obvious shallow trenches, and the stand density of cypress reached a certain amount, replanting cypress to form an clumped distribution pattern could further reduce peak flow. When the characteristics of micro-topography reached the conditions for significantly increasing the peak flow, the spatial pattern of cypress could be changed to reduce peak flow.

4.2. Differences in the impact of different spatial pattern of cypress, micro-topography and rainfall conditions on peak flow

In this study, the results in Table 2 show that with the increase of the rainfall intensity, the hindering effect of different underlay conditions to surface runoff decreased, which indicates that the promotion (inhibition) of peak flow by micro-topography or the spatial pattern of cypress was enhanced (weakened). Studies have shown that the micro-topography mainly affects the runoff velocity during the runoff process, which was specifically reflected in the surface resistance provided by the surface roughness, the confluence channel provided by the runoff path, and the change of runoff energy caused by topography relief (Govers et al., 2000; Zheng et al., 2014). With the increase of rainfall intensity, on the one hand, the preparation time for the consumption of runoff energy on the rough surface is reduced and the time for water to reach the runoff path is shortened (Darboux et al., 2010), thereby accelerating the self-organization process of confluence network on the slope (Zehe et al., 2013), which was the main reason why the runoff time to reach the peak flow under high rainfall intensity was significantly less than that of low rainfall intensity.

On the other hand, under steep slope conditions, the downstream-moving force produced by rainfall was greater than the upstream-moving force, which could reduce the resistance of the surface flow and increase the flow velocity on the slope, and the decreased effect of resistance would increase with an increase in rainfall intensity (Yang et al., 2018). Therefore, the increase in rainfall intensity increased the promotion effect of micro-topography on the peak flow. In addition, among the different runoff plots in Table 2, the increase in the peak flow coefficient varied among the plots with the increase of rainfall intensity. The main reason was that under different combinations of micro-topography and the spatial pattern of cypress, the dominant factors affecting the peak flow also were different.

\section{Conclusions}

Rainfall intensities and the combinations of micro-topography and the spatial pattern of cypress had an important impact on the runoff process, especially reflected in the impact on the peak flow. Under the condition of moderate rainfall or rainstorm, among the characteristic parameters of micro-topography and the spatial pattern of cypress, topographic relief, surface roughness, runoff path density, contagion index of cypress and stand density of cypress were the key factors affecting the peak flow, and when the rainfall intensity exceeded a certain level (severe rainstorm). The factors previously mentioned were no longer the dominant factors affecting peak flow.

With the increase in rainfall intensity, the hindering effect of different underlay conditions on surface runoff decreased. This was specifically reflected in the changes in the degree of impact of the factors of microtopography and the spatial pattern of cypress on the peak flow. Subsequent studies should be done on the rainfall intensity thresholds corresponding to the effect of each factor on the peak flow, so as to propose an optimization for the underlay conditions to achieve the purpose of efficiently controlling soil erosion on a slope. 


\section{Acknowledgments}

This research was supported by the National Key Research and Development Program of China (No. 2017YFC0505602)

\section{Declaration of interests}

The authors declare that they have no known competing financial interests or personal relationships that could have appeared to influence the work reported in this paper.

\section{References}

Aguirre O., Hui G., Gadow K.V., Jiménez J. 2003. An analysis of spatial forest structure using neighbourhood-based variables. Forest Ecology \& Management, 183(1-3):137-145.

Bai X.Y., Wang S.J., Xiong K.N. 2012. Assessing spatial-temporal evolution processes of karst rocky desertification land: Indications for restoration strategies. Land Degradation \& Development, 24(1):47-56.

Bautista S., Mayor A.G., Bourakhouadar J., Bellot Y. 2007. Plant spatial pattern predicts hillslope runoff and erosion in a semiarid Mediterranean landscape. Ecosystems, 10(6):987-998.

Besag J.E. 1977. Contribution to the discussion on Dr. Ripley's paper. J. R. Stat. Soc. Ser, 39

Bochet E., Poesen J., Rubio J.L. 2015. Mound development as an interaction of individual plants with soil, water erosion and sedimentation processes on slopes. Earth Surface Processes \& Landforms, 25(8):847-867.

Burylo M., Rey F., Bochet E., Dutoit T. 2012. Plant functional traits and species ability for sediment retention during concentrated flow erosion. Plant \& Soil, 353(1-2):135-144.

Darboux F., Gascuelodoux C., Davy P. 2010. Effects of surface water storage by soil roughness on overlandflow generation. Earth Surface Processes \& Landforms, 27(3):223-233.

Deng P.D. 2014. Study on the flood-peak runoff coefficient method of urban storm water pipe design and mathematic model. Water \& Wastewater Engineering, 000(005):108-112. [in Chinese]

Du H., Hu F., Zeng F., Wang K., Peng W., Zhang H., Zeng Z., Zhang F., Song T. 2017. Spatial distribution of tree species in evergreen-deciduous broadleaf karst forests in southwest China. Scientific Reports, 7(1):15664.

Duan L., Huang M., Zhang L. 2016. Differences in hydrological responses for different vegetation types on a steep slope on the Loess Plateau, China. Journal of Hydrology, 537: 356-366.

Efe, R. 2014. Ecological properties of vegetation formations on karst terrains in the central Taurus Mountains (Southern Turkey). Procedia - Social and Behavioral Sciences, 120:673-679.

El Kateb H., Zhang H., Zhang P., Mosandl R. 2013. Soil erosion and surface runoff on different vegetation covers and slope gradients: A field experiment in Southern Shaanxi Province, China. Catena, 105:1-10.

Febles-Gonzalez J.M., Vega-Carreno M.B., Tolon-Becerra A., Lastra-Bravo X. 2011. Assessment of soil erosion in karst regions of Havana, Cuba. Land Degradation \& Development, 23(5):465-474.

Fu B.J., Zhao W.W., Chen L.D.,Liu, Z.F., Lu, Y.H. 2005.Eco-hydrological effects of landscape pattern change.Landscape and Ecological Engineering, 1(1):25-32.

Gonzalez-Arqueros M.L., Navarette-Segueda A., Mendoza M.E. 2018. Modeling biophysical and anthropogenic effects on soil erosion over the last 2,000 years in central Mexico. Land Degradation \& Development, 29(6):1885-1895.

Govers G., Takken I., Helming K. 2000. Soil roughness and overland flow. Agronomie, 20(2):131-146.

Harman C. J., Lohse K. A., Troch P. A., Sivapalan M. 2014. Spatial patterns of vegetation, soils, and microtopography from terrestrial laser scanning on two semiarid hillslopes of contrasting lithology. Journal of Geophysical Research: Biogeosciences, 119(2): 163-180. 
He J.J., Sun L.Y., Gong H.L., Cai Q.G., Jia L.J. 2016. The characteristics of rill development and their effects on runoff and sediment yield under different slope gradients. Journal of Mountain Science, 13(3):397-404.

Hou G.R., Bi H.X., Huo Y.M., Wei X., Zhu Y., Wang X., Liao W. 2020. Determining the optimal vegetation coverage for controlling soil erosion in Cynodon dactylon grassland in North China, Journal of Cleaner Production, 244, 118771.

Imeson A.C., Prinsen H.A.M. 2004. Vegetation patterns as biological indicators for identifying runoff and sediment source and sink areas for semi-arid landscapes in Spain. Agriculture Ecosystems \& Environment, 104(2):333-342.

Ito H., Ito S., Matsuda A., Mitsuda Y., Buckley G.P. 2017. The effect of micro-topography on habitat segregation and tree species diversity in a warm temperate evergreen broadleaved secondary forest in southern Kyushu, Japan. Vegetation Science, 24(2):171-182.

Kim D., Kupfer J.A. 2016. Tri-variate relationships among vegetation, soil, and topography along gradients of fluvial biogeomorphic succession. Plos One, 11(9):e0163223.

Lan G., Hu Y., Cao M., Zhu H. 2011. Topography related spatial distribution of dominant tree species in a tropical seasonal rain forest in China. Forest Ecology \& Management, 262(8):1507-1513.

Liu J.T., Han X.L., Liu J.L., Liang Z.M., He R.M. 2019. Understanding of critical zone structures and hydrological connectivity: A review. Advances in Water Science, 030(001):112-122. [in Chinese]

Meerveld T.V., Mcdonnell J.J. 2006. Threshold relations in subsurface stormflow: 1. A 147-storm analysis of the Panola hillslope. Water Resources Research, 42:W02410.

Miliša M., Belančic A., Kepčija R.M., Perić M.S. 2010. Calcite deposition in karst waters is promoted by leaf litter breakdown and vice versa. Annales de Limnologie - International Journal of Limnology, 46(4):225-232.

Normark W.R., Spiess F.N. 1976. Erosion on the line islands archipelagic apron: Effect of small-scale topographic relief. Geological Society of America Bulletin, 87(2):286.

Ochoa P.A., Fries A., Mejía D., Burneo J.I., Ruíz-Sinoge J.D., Cerdà A. 2016. Effects of climate, land cover and topography on soil erosion risk in a semiarid basin of the Andes. Catena, 140, 31-42.

Pommerening A. 2002. Approaches to quantifying forest structures. Forestry (3):305-324.

Puigdefábregas J. 2010. The role of vegetation patterns in structuring runoff and sediment fluxes in drylands. Earth Surface Processes \& Landforms, 30(2):133-147.

Qin W., Cao W.H., Guo Q.K., Yu Y., Yin Z. 2017. Review of the effects of vegetation patterns on soil erosion and sediment yield. Acta Ecologica Sinica, (14): 4905-4912. [in Chinese]

Ren K.M., Wei W., Zhao X.N., Feng T. 2018. Simulation of the effect of slope vegetation cover and allocation pattern on water erosion in the loess hilly region. Acta Ecologica Sinica, 38(22): 8031-8039. [in Chinese]

Ren Z.Y., Zhu Q.K., Zhang Q.N., Ma H., Huang Z.J. 2016. Effect of slope micro-topography on spatial distribution of trees in Loess Area of north Shaanxi Province,China. Forest Research, 29( 3):389-394. [in Chinese]

Ripley B.D. 1977. Modeling spatial patterns. Journal of the Royal Statal Society Series B (Statal Methodology), 9:178-212.

Romkens M.J.M., Helming K., Prasad S.N. 2002. Soil erosion under different rainfall intensities, surface roughness, and soil water regimes. Catena, 46(2-3):103-123.

Saco P.M., Mariano M.D.L.H. 2013. Ecogeomorphic coevolution of semiarid hillslopes: Emergence of banded and striped vegetation patterns through interaction of biotic and abiotic processes. Water Resources Research, 49(1): 115-126. 
Slattery M.C., Burt T.P. 2015. Particle size characteristics of suspended sediment in hillslope runoff and stream flow. Earth Surface Processes \& Landforms, 22(8):705-719.

Song S.S., Li H.X., Zhang J.G. 2003. Micro-topographic structures study of individual plants on Loss Plateau. Journal of Mountain Research, 21(1): 106-109. [in Chinese]

Székely B., Telbisz T., Koma Z., Kelemen K., Szmorad F., Deák M., Látos T., Standovár T 2015. Geomorphometric correlations of vegetation cover properties and topographic karst features based on high-resolution LiDAR DTM of Aggtelek Karst, NE Hungary, Egu General Assembly Conference.

Vandenbruwaene W., Temmerman S., Bouma T.J., Klaassen P.C., de Vries M.B., Callaghan D.P., van Steeg P., Dekker R., van Duren L.A., Martini E., Biermans G., Schoelynck J., Meire P. 2011. Flow interaction with dynamic vegetation patches: Implications for biogeomorphic evolution of a tidal landscape. Journal of Geophysical Research: Earth Surface, 116(F01008).

Wang L.H., Wang Y.F., Wang J., Lin Q.T., Wu F.Q. 2018. Effects of soil surface roughness on runoff generation mechanism on loess slope. Transactions of the Chinese Society of Agricultural Engineering, 34(005):120128. [in Chinese]

Xu C., Yang Z., Qian W., Chen S., Liu X., Lin W., Xiong D., Jiang M., Chang C.T., Huang J.C., Yang Y. (2019). Runoff and soil erosion responses to rainfall and vegetation cover under various afforestation management in subtropical montane forest. Land Degradation and Development, 2019.30(14):1711-1724.

Yang P.P., Wang Y.Q., Zhang H.L., Wang Y.J. 2018. Characteristics of overland flow resistance under interaction of rainfall intensity and unit discharge and surface roughness. Transactions of the Chinese Society of Agricultural Engineering, 34(006):145-151. [in Chinese]

Zehe E., Ehret U., Blume T., Kleidon A., Scherer U., Westhoff M. 2013 A thermodynamic approach to link self-organization, preferential flow and rainfall-runoff behaviour Hydrology and Earth System Science, 17(11), 4297-4322.

Zhang G.H., Liu G.B., Yi L. 2014. Effects of vegetation patterns on overland flow resistance. Journal of Soil and Water Conservation, 28(004):55-59. [in Chinese]

Zhang Z.H., Hu G., Ni J. 2015. Spatial distribution patterns and their fractal properties for trees in a subtropical mixed evergreen-deciduous broad-leaved karst forest in Maolan, southwestern China. Acta Ecologica Sinica, 35(24) : 8221-8230. [in Chinese]

Zhao J.L., Govers G. 2016. Variations in vegetation cover and topography control gully density and sediment production on the Chinese Loess Plateau, EGU General Assembly Conference. EGU General Assembly Conference Abstracts.

Zhao Q., Zhang Y., Xu S., Ji X., Wang S., Ding S. 2019. Relationships between riparian vegetation pattern and the hydraulic characteristics of upslope runoff. Sustainability, 11, 2966.

Zheng Z.C., He S.Q., Wu F.Q. 2014. Changes of soil surface roughness under water erosion process. Hydrological Processes, 28(12):1-11. 
Table 1

Characteristics of each runoff plot (note: DBH means diameter at breast height)

\begin{tabular}{|c|c|c|c|c|c|c|c|}
\hline No. & $\begin{array}{l}\text { Average crown width of cypress } \\
\text { (Cupressus funebris) (m) }\end{array}$ & $\begin{array}{l}\text { Average height of cypress } \\
\text { (Cupressus funebris) (m) }\end{array}$ & $\begin{array}{l}\text { Average DBH of cypress } \\
\text { (Cupressus funebris) }\end{array}$ & Surface vegetation community & $\begin{array}{c}\text { Surface vegetation } \\
\text { coverage }(\%)\end{array}$ & $\begin{array}{c}\text { Soil thickness } \\
(\mathrm{cm})\end{array}$ & $\begin{array}{l}\text { The relative height } \\
\text { difference ( } m \text { ) }\end{array}$ \\
\hline 1 & $0.8 \times 1.0$ & 2.91 & 2.65 & $\begin{array}{l}\text { Ilex chinensis, Rhamnus davurica, } \\
\text { Themeda japonica }\end{array}$ & 58.4 & 22.1 & 8.33 \\
\hline 2 & $0.9 \times 1.0$ & 2.72 & 2.45 & $\begin{array}{l}\text { Rhamnus davurica, Themeda } \\
\text { japonica }\end{array}$ & 55.8 & 21.8 & 8.12 \\
\hline 3 & $0.8 \times 9.9$ & 2.54 & 3.15 & $\begin{array}{l}\text { Coriaria nepalensis, Rhamnus } \\
\text { davurica, Themeda japonica }\end{array}$ & 59.2 & 22.0 & 8.03 \\
\hline 4 & $0.8 \times 0.8$ & 2.83 & 2.68 & Daphne genkwa, Themeda japonica & 55.0 & 23.4 & 8.17 \\
\hline 5 & $0.9 \times 1.0$ & 2.69 & 3.09 & $\begin{array}{l}\text { Vitex negundo, Coriaria nepalensis, } \\
\text { Themeda japonica }\end{array}$ & 57.4 & 24.5 & 8.44 \\
\hline 6 & $0.9 \times 1.1$ & 2.40 & 3.02 & Rosa cymosa, Themeda aponica & 53.5 & 25.3 & 8.32 \\
\hline 7 & $0.8 \times 1.0$ & 2.32 & 2.78 & Daphne genkwa, Themeda japonica & 58.8 & 24.5 & 8.10 \\
\hline 8 & $0.9 \times 1.0$ & 2.76 & 3.04 & $\begin{array}{l}\text { Rhamnus davurica, Ixeris } \\
\text { denticulate, Themeda japonica }\end{array}$ & 57.1 & 23.8 & 8.22 \\
\hline 9 & $0.8 \times .9$ & 2.46 & 2.32 & $\begin{array}{l}\text { Coriaria nepalensis, Rhamnus } \\
\text { davurica, Themeda japonica }\end{array}$ & 52.0 & 23.6 & 8.03 \\
\hline 10 & $0.8 \times 9.9$ & 2.12 & 2.73 & $\begin{array}{l}\text { Rhamnus davurica, Ixeris } \\
\text { denticulate Themeda japonical }\end{array}$ & 58.2 & 22.5 & 8.13 \\
\hline
\end{tabular}


Table 2

Differences in peak flow coefficient for each runoff plot under different rainfall conditions

\begin{tabular}{|c|c|c|c|c|c|c|c|c|c|c|}
\hline & 1 & 2 & 3 & 4 & 5 & 6 & 7 & 8 & 9 & 10 \\
\hline $\begin{array}{l}\text { Moderate rainfall } \\
\text { condition }\end{array}$ & 0.219 & 0.240 & 0.141 & 0.164 & 0.257 & 0.138 & 0.150 & 0.089 & 0.141 & 0.087 \\
\hline $\begin{array}{l}\text { Rainstorm } \\
\text { condition }\end{array}$ & 0.230 & 0.239 & 0.224 & 0.235 & 0.282 & 0.190 & 0.202 & 0.117 & 0.175 & 0.138 \\
\hline $\begin{array}{l}\text { Severe rainstorm } \\
\text { condition }\end{array}$ & 0.316 & 0.340 & 0.342 & 0.324 & 0.514 & 0.293 & 0.422 & 0.307 & 0.369 & 0.354 \\
\hline
\end{tabular}


Table 3

Pearson's ceefficients of bivariate correlations between the characteristic parameters of the spatial pattern of cypress (Cupressus funchris) and micro-topooradty

\begin{tabular}{|c|c|c|c|c|c|c|c|c|c|}
\hline & $\begin{array}{c}\text { Topographic } \\
\text { relief }\end{array}$ & $\begin{array}{c}\text { Surface } \\
\text { roughness }\end{array}$ & $\begin{array}{c}\text { Surface } \\
\text { cutting depth }\end{array}$ & $\begin{array}{l}\text { Runoff path } \\
\text { density }\end{array}$ & $\begin{array}{l}\mathrm{L}(\mathrm{d}) \text { index of } \\
\text { cypress } \\
\text { (Cupressus } \\
\text { funebris) }\end{array}$ & $\begin{array}{c}\text { Contagion index } \\
\text { of cypress } \\
\text { (Cupressus } \\
\text { funebris) }\end{array}$ & $\begin{array}{l}\text { Stand density of } \\
\text { cypress } \\
\text { (Cupressus } \\
\text { funebris) }\end{array}$ & $\begin{array}{c}\text { Peak flow } \\
\text { (Moderate } \\
\text { rainfall) }\end{array}$ & $\begin{array}{r}\begin{array}{r}\text { Peak flow } \\
\text { (Rainstormm }\end{array} \\
\end{array}$ \\
\hline Surface roughness & -0.328 & & & & & & & & \\
\hline Surface cutting dephth & 0.132 & -0.513 & & & & & & & \\
\hline Runoff path density & 0.101 & $-0.645^{*}$ & 0.496 & & & & & & \\
\hline $\begin{array}{l}\mathrm{L}(\mathrm{d}) \text { index of cypress } \\
\text { (Cupressus funebris) }\end{array}$ & 0.186 & 0.052 & 0.455 & -0.345 & & & & & \\
\hline $\begin{array}{l}\text { Contagion index of } \\
\text { cypress (Cupressus } \\
\text { funcbris) }\end{array}$ & $-0.737 *$ & 0.228 & 0.169 & -0.316 & 0.170 & & & & \\
\hline $\begin{array}{l}\text { Stand density of cypress } \\
\text { (Cupressus funebris) }\end{array}$ & -0.358 & 0.547 & -0.202 & -0.486 & -0.208 & 0.559 & & & \\
\hline $\begin{array}{l}\text { Peak flow (Moderate } \\
\text { rainfall) }\end{array}$ & $0.685^{*}$ & $-0.744^{n}$ & 0.571 & $0.736^{*}$ & 0.080 & $-0.6477^{*}$ & $-0.691 *$ & & \\
\hline Peak flow (Rainstorm) & $0.693^{*}$ & $-0.656^{*}$ & 0.237 & $0.689^{*}$ & -0.157 & $-0.749^{\star}$ & $-0.717^{*}$ & $0.898^{* *}$ & \\
\hline $\begin{array}{c}\text { Peak flow (Severe } \\
\text { rainstorm) }\end{array}$ & $0.760^{*}$ & -0.073 & 0.275 & -0.025 & 0.389 & -0.421 & -0.161 & 0.455 & 0.481 \\
\hline
\end{tabular}


Table 4

Correlation between peak flow and the composite indexes of the spatial pattern of cypress (Cupressus funebris) and micro-topography

Peak flow Composite index of topography Composite index of the spatial pattern of cypress (Cupressus funebris)

\begin{tabular}{lll}
\hline Peak flow(Moderate rainfall) & $0.929^{* *}$ & $-0.758^{*}$ \\
\hline
\end{tabular}

\begin{tabular}{ll} 
Peak flow(Rainstorm) $\quad 0.857^{* *}$ & $-0.816^{* *}$ \\
\hline
\end{tabular}

${ }^{*}$ denotes significant differences at $\mathrm{P}<0.05$ level, and $* *$ denotes significant differences at $\mathrm{P}<0.01$. 


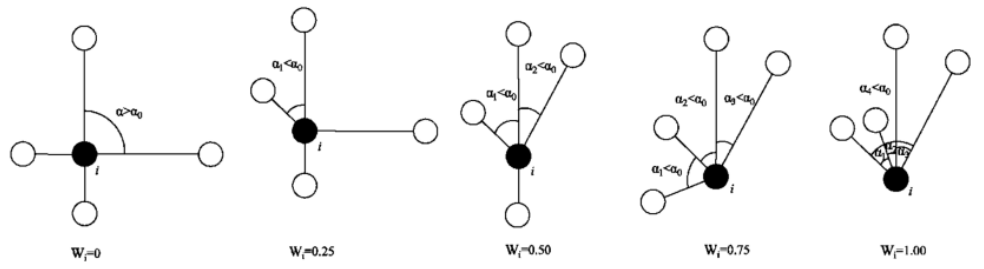

Fig.1. Value range and meaning of the contagion index $\mathrm{W}_{\mathrm{i}}\left(\mathrm{W}_{\mathrm{i}}=0\right.$, four $\alpha$ angles all are greater than or equal to $\alpha_{0} ; W_{i}=0.25$, only one $\alpha$

angles is smaller than $\alpha_{0} ; W_{i}=0.50$, only two $\alpha$ angles are smaller than $\alpha_{0} ; W_{i}=0.75$, only three $\alpha$ angles are smaller than $\alpha_{0} ; W_{i}=1.00$,

four $\alpha$ angles are all smaller than $\alpha_{0}$ ) 


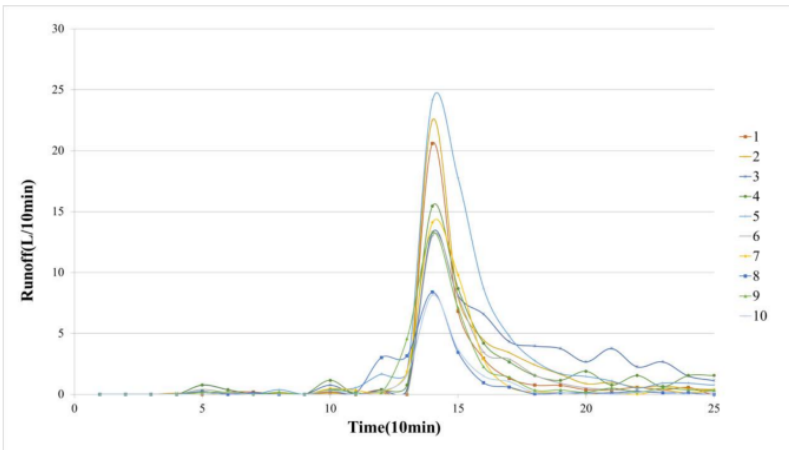

Fig.2. Surface runoff under moderate rainfall (33.8 mm/24 h) on July 22, 2019 


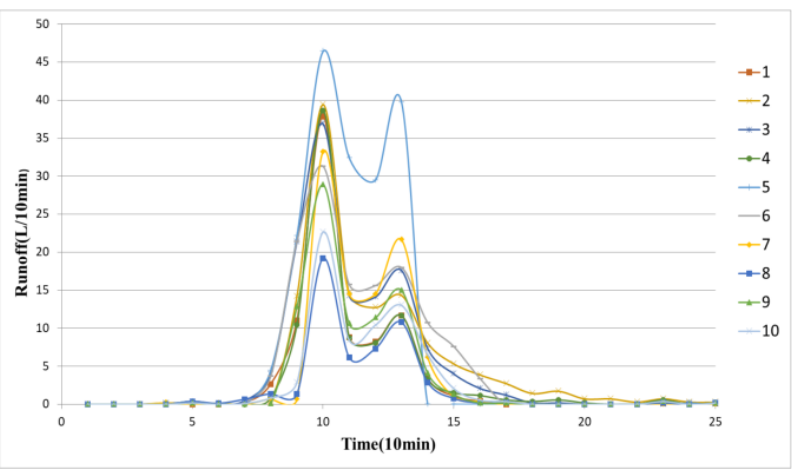

Fig.3. Surface runoff under rainstorm ( $51.8 \mathrm{~mm} / 24 \mathrm{~h}$ ) on June 29, 2019 


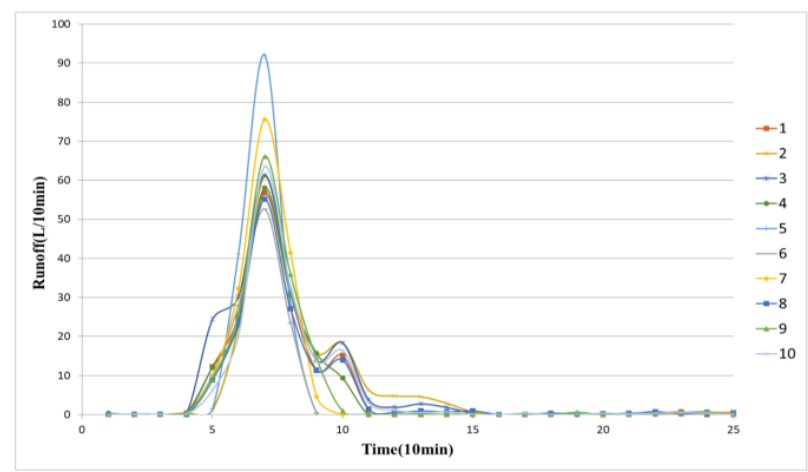

Fig.4. Surface runoff under severe rainstorm (72.2 mm/24 h) on August 8, 2019 


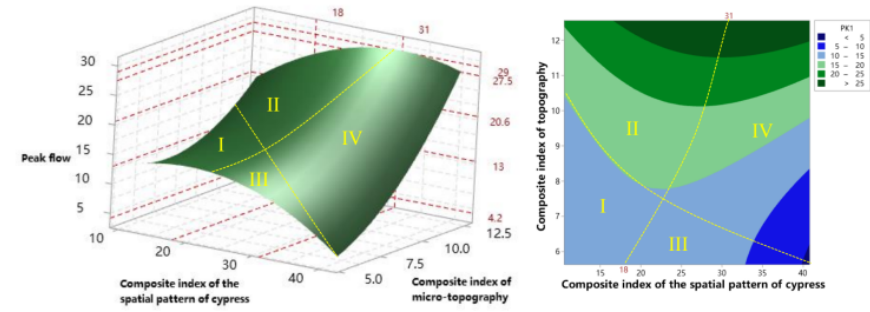

Fig.5. Response surface of the peak flow to the coupling of the composite index of the spatial pattern of cypress (Cupressus funebris) and the composite index of micro-topography (note: PK1 means peak flow under moderate rainfall) 


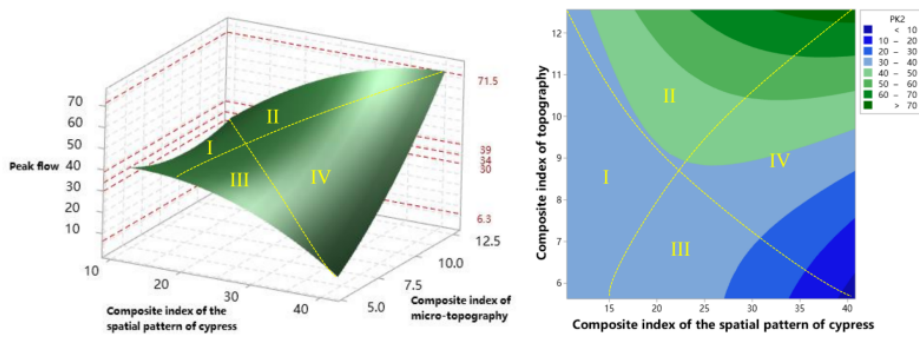

Fig.6. Response surface of the peak flow to the coupling of the composite index of the spatial pattern of cypress (Cupressus funebris) and the composite index of micro-topography (note: PK2 means peak flow under rainstorm) 